\title{
Clinicopathological characteristics of unicentric retroperitoneal Castleman's disease: a study of 14 cases
}

\author{
Shuai Wang ${ }^{1}$, Shanwen Chen ${ }^{2 *}$, Jiangfeng $\mathrm{Xu}^{1}$ and Songliang $\mathrm{Cai}^{2}$
}

\begin{abstract}
Background: The objectives of this study are to investigate the clinicopathological characteristics and prognosis analysis of unicentric retroperitoneal Castleman's disease (CD), and to improve the level of diagnosis and treatment of unicentric retroperitoneal CD.

Methods: The clinical data of 14 patients with unicentric retroperitoneal CD undergoing surgery from September 2007 to March 2014 were retrospectively reviewed.

Results: There were six males and eight females with a median age of 39 years old (range 15-58). Only three patients had a clinical manifestation of abdominal pain, and one patient associated with myasthenia gravis. All patients underwent surgical resection. The mean operation time was $137 \mathrm{~min}$ with a range of 72-472 min. The mean blood loss was $143 \mathrm{ml}$ (range 50-500 ml). The CD was confirmed by histopathology. There were hyaline vascular (HV) type of CD in 13 cases, and mixed type of CD in one case. The mean hospital stay was 17.9 days with a mean postoperation hospital stay of 9.2 days. The duration of follow-up ranged from 21 to 99 months for 14 cases. All the 14 patients were alive without recurrence.

Conclusions: Unicentric retroperitoneal CD is a rare disease that is often misdiagnosed due to the absence of specific clinical manifestations. The final diagnosis depends on pathologic examination. Complete surgical resection of the tumor is the best therapeutic alternative for unicentric CD.
\end{abstract}

Keywords: Unicentric retroperitoneal Castleman's disease, Surgery, Clinicopathological characteristics

\section{Background}

Castleman's disease (CD) was first described in 1956 by Benjamin Castleman, who identified a series of patients with solitary hyperplastic mediastinal lymph nodes containing small, hyalinized follicles, and marked interfollicular vascular proliferation [1]. The etiology is unknown, and it is characterized by the development of tumorous masses of lymphoid tissue. Two clinical types (unicentric and multicentric) have been subclassified on histological forms: hyaline vascular (HV) type, plasma cell (PC) type, and mixed type. As this disease is rare and poorly understood, the optimal therapy is unknown. This study was conducted to analyze the

\footnotetext{
* Correspondence: 781835570@qq.com

Urology Surgery, The first affiliated hospital Zhejiang University School of Medicine, Qingchun Road No. 79, Hangzhou, Zhejiang 310000, China Full list of author information is available at the end of the article
}

clinicopathological characteristics and surgical treatment for patients with unicentric retroperitoneal CD.

\section{Methods}

From September 2007 to October 2015, a total of 14 patients with unicentric retroperitoneal $C D$ were managed at our hospital. These patients were retrieved from our pathology database, and the medical records were reviewed for demographic data, clinical and pathological characteristics. The extent of the disease was assessed with the help of ultrasonography (US) and computed tomography $(\mathrm{CT})$ of the abdomen and routine blood chemistry analyses. The diagnosis of $\mathrm{CD}$ was made based on the postoperative histological examination. Pathologically, hyaline vascular CD had hyaline vascular follicles and interfollicular capillary proliferation. Plasma cell CD was characterized by follicular 
hyperplasia with intervening sheets of plasma cells. If the features of both types were present, it was diagnosed as mixed type. The diagnosis of these types was based on the criteria of Keller et al. [2].

The end-points were survival and recurrence. Followup information was obtained. All patients were either followed in our clinic or by telephone contact anywhere possible until the time of the patients' death or till the end of this study. The duration of follow-up was defined as the interval between diagnosis and the last contact with each patient. Local recurrence was defined as tumor relapse within the region of operative files.

\section{Results}

The study included all 14 cases of histologically confirmed CD at our hospital from September 2007 to March 2014. The relevant clinical findings of all the 14 cases are summarized in (Table 1). Eight patients (57\%) were female and six (43\%) were male, with a median age of 39 years old and a range of 15-58 years. Ten patients were asymptomatic, and masses were identified either incidentally or by physical examination. Only three patients had a clinical manifestation of abdominal pain or uncomfortable, and one patient associated with myasthenia gravis. The medical history and laboratory findings of these patients were unremarkable. The tumor marker of all cases, including CA-125, CA-19-9, CEA, AFP, were normal. The tumor size determined by either US or CT ranged from $3.0 \times 2.5 \times 1.8$ to $7.0 \times 7.5 \times$ $5.0 \mathrm{~cm}$. In all the patients, the diagnosis of $\mathrm{CD}$ was confirmed after the resection and histological examination of the specimen. Thirteen patients had HV type and one patient had mixed type.
No patients were preoperatively suspected of CD, but other diseases. No patients received any steroids or immunotherapy because no one was suspected of autoimmune diseases. All patients underwent surgical resection. Preoperative biopsy for a definitive diagnosis was excluded in concern of the deep position and the possibility of hemorrhea. Preoperation diagnosis and surgical information are summarized in (Table 2). The mean operation time was 137 min with a range of $72-472 \mathrm{~min}$. The mean blood loss was $143 \mathrm{ml}$ (range $50-500 \mathrm{ml}$ ). Three patients had a surgical approach of laparoscopy. The two of them underwent laparoscopic transperitoneal approach and the other one underwent laparoscopic retroperitoneal approach. Distal pancreatectomy was carried out unitedly in the two patients because of a preoperation misdiagnosis of occupation of pancreas. Only one patient received blood transfusion and he was sent to intensive care unit (ICU) because of massive hemorrhage. The reason of the other patient who was also sent to ICU was postoperative myasthenic crisis. The mean hospital stay was 17.9 days with a mean postoperation hospital stay of 9.2 days. No patients received chemotherapy or radiotherapy after surgical resection.

The mean duration of follow-up was 49.9 months (range 21-99 months). All patients received US or CT when they came back to clinic, and they no longer showed symptoms or evidence of disease after surgical resection within follow-up period. Incisional hernia happened in one patient as a complication, and hydrops in the operation area happened in two patients. No other complications were found in all the patients. All the patients had no need to take medicine of steroids or received immunotherapy after operation.

Table 1 Patients and treatment, and survival in unicentric retroperitoneal CD

\begin{tabular}{|c|c|c|c|c|c|c|c|}
\hline Patient $(n)$ & Age (years) & Sex & Histological type & Treatment & Hospital stay (days) & Follow-up (months) & Outcome \\
\hline 1 & 39 & $\mathrm{~F}$ & $\mathrm{HV}$ & $C R$ & 15 & 80 & A-NED \\
\hline 2 & 30 & M & HV & $C R$ & 20 & 61 & A-NED \\
\hline 3 & 31 & $\mathrm{~F}$ & HV & $C R$ & 18 & 59 & A-NED \\
\hline 4 & 15 & $\mathrm{~F}$ & $\mathrm{HV}$ & $C R$ & 13 & 46 & A-NED \\
\hline 5 & 44 & M & HV & $C R$ & 26 & 40 & A-NED \\
\hline 6 & 58 & $\mathrm{~F}$ & $\mathrm{HV}$ & $C R$ & 12 & 40 & A-NED \\
\hline 7 & 32 & $\mathrm{~F}$ & $\mathrm{HV}$ & $C R$ & 21 & 33 & A-NED \\
\hline 8 & 40 & M & MIX & $C R$ & 15 & 30 & A-NED \\
\hline 9 & 39 & $\mathrm{~F}$ & $\mathrm{HV}$ & $C R$ & 9 & 26 & A-NED \\
\hline 10 & 24 & M & HV & $C R$ & 38 & 22 & A-NED \\
\hline 11 & 52 & M & HV & $C R$ & 23 & 20 & A-NED \\
\hline 12 & 51 & $F$ & $\mathrm{HV}$ & $C R$ & 11 & 3 & A-NED \\
\hline 13 & 29 & M & $\mathrm{HV}$ & $C R$ & 14 & 2 & A-NED \\
\hline 14 & 42 & $\mathrm{~F}$ & $\mathrm{HV}$ & $C R$ & 16 & 17 & A-NED \\
\hline
\end{tabular}

A-NED alive and no evidence of disease, $C R$ complete resection, $F$ female, $M$ male, $H V$ hyaline vascular type, $M I X$ mixed type 
Table 2 Preoperation diagnosis and surgical information

\begin{tabular}{|c|c|c|c|c|c|c|c|}
\hline Patient $(n)$ & Preoperation diagnosis & $\begin{array}{l}\text { Greatest diameter } \\
\text { of lesion }(\mathrm{cm})\end{array}$ & $\begin{array}{l}\text { Operation time } \\
\text { (min) }\end{array}$ & $\begin{array}{l}\text { Blood loss } \\
(\mathrm{ml})\end{array}$ & Surgical approach & $\begin{array}{l}\text { Transfer to } \\
\mathrm{ICU}\end{array}$ & $\begin{array}{l}\text { Postoperation } \\
\text { hospital stay (days) }\end{array}$ \\
\hline 1 & Occupation of pancreas & 6 & 87 & 100 & O-TA & $\mathrm{N}$ & 9 \\
\hline 2 & $\begin{array}{l}\text { Occupation of hepatic } \\
\text { caudate lobe }\end{array}$ & 6 & 105 & 150 & O-TA & $\mathrm{N}$ & 10 \\
\hline 3 & Occupation of right adrenal & 6 & 127 & 100 & L-RA & N & 6 \\
\hline 4 & Ectopic pheochromocytoma & 3 & 135 & 100 & L-RA & N & 7 \\
\hline 5 & Retroperitoneal tumor & 3 & 134 & 100 & O-TA & N & 9 \\
\hline 6 & Occupation of pancreas & 4.2 & 72 & 150 & O-TA & N & 10 \\
\hline 7 & Retroperitoneal tumor & 5.5 & 80 & 50 & O-RA & N & 8 \\
\hline 8 & Retroperitoneal tumor & 5.5 & 125 & 100 & O-TA & $\mathrm{N}$ & 9 \\
\hline 9 & Retroperitoneal tumor & 6 & 121 & 100 & O-TA & N & 6 \\
\hline 10 & Occupation of pancreas & 7.5 & 472 & 200 & L-TA & N & 24 \\
\hline 11 & Occupation of right adrenal & 7.5 & 159 & 500 & O-TA & Y & 9 \\
\hline 12 & Retroperitoneal tumor & 5.5 & 107 & 100 & O-TA & $\mathrm{N}$ & 6 \\
\hline 13 & Retroperitoneal tumor & 5 & 116 & 200 & O-TA & Y & 7 \\
\hline 14 & Retroperitoneal tumor & 4 & 80 & 50 & O-TA & N & 9 \\
\hline
\end{tabular}

O-TA open transperitoneal approach, O-RA open retroperitoneal approach, L-TA laparoscopic transperitoneal approach, L-RA laparoscopic retroperitoneal approach, $N$ no, $Y$ yes, $d$ day, ICU intensive care unit

\section{Discussion}

$\mathrm{CD}$ is a rare, nonneoplastic and lymphoproliferative disorder that can occur in any site where lymph nodes are present, which is a rare diagnosis in departments all over the world and remains detectable at relatively low levels. Most commonly involved sites are the mediastinum (60\%), retroperitoneum (11\%), and axilla (4\%) [3]. The etiology of $\mathrm{CD}$ remains unclear, although several immunological mechanisms have been proposed, including overproduction of IL- 6 and human herpes virus type 8 infection [4]. Dysplastic or atypical follicular dendritic cells positive for CD21 and CD35 have frequently been described in the hyalinized center and also in the cytology smears, and can even show monoclonality, yet their role in the pathogenesis is unclear [5-7].

$\mathrm{CD}$ was divided into three subgroups based on its histology, which were hyaline vascular type, plasma cell type, and mixed type, and can be divided into two further forms on the basis of clinical criteria: the more common unicentric form and the less common multicentric form. The unicentric $\mathrm{CD}$ corresponds to the hyaline vascular variant (>90\%). Clinically, unicentric $\mathrm{CD}$ tends to be present in the form of an enlarged, benign, painless lymph node that generally remains asymptomatic unless it begins to compress adjacent structures or is discovered fortuitously at the time of a routine physical examination, which occurs in young people and associated with a benign clinical course. In the current literature, unicentric $\mathrm{CD}$ was asymptomatic in $31 \%$ of patients and symptomatic in $69 \%$ of patients [8,9], while $28.6 \%$ patients were found as associated symptoms in our patients with unicentric retroperitoneal CD. It is difficult to differentiate $\mathrm{CD}$ from other tumors before pathologic diagnosis is confirmed. Some kinds of tumors which located in the retroperitoneal region commonly are listed in Table 3.

There is no definitive standard treatment regimen for unicentric $\mathrm{CD}$. This study illustrated that the standard therapy of unicentric $C D$ is surgical excision, which has been proven to be curative upon complete resection and en bloc. Complete surgical excision is the mainstay of treatment and is virtually curative in all cases reported thus far, with a 5-year survival rate approaching $100 \%$ [2, 10]. Keller et al. reported that all their cases of unicentric $C D$ had an indolent clinical course and mild biological behaviors, with the elimination of all systemic symptoms after complete resection [2]. Bowne et al. studied 16 cases of $C D$ and reported that no clinical or radiographic recurrence of symptoms was found among the 8 of 16 cases of unicentric hyaline-vascular disease patients who underwent complete surgical excision [9]. There are several reports that unicentric $C D$ in the abdominal cavity were treated laparoscopically [11, 12]. Some masses are well vascularized and adjacent to the great vessels [11]; laparoscopy can offer magnified images to facilitate and secure dissection. In our case studies, all the 14 patients with unicentric retroperitoneal CD underwent a complete surgical resection, either open or laparoscopy, and survived with excellent prognosis. 
Table 3 Differential diagnosis

\begin{tabular}{llll}
\hline & Clinical manifestations & Pathological features & Microscopic features \\
\cline { 3 - 4 } Castleman's disease & $\begin{array}{l}\text { Asymptomatic; may associated with } \\
\text { autoimmune diseases; divided into } \\
\text { unicentric type and multicentric type }\end{array}$ & $\begin{array}{l}\text { Well-circumscribed, encapsulated mass, } \\
\text { reddish-brown }\end{array}$ & $\begin{array}{l}\text { Divided into hyaline-vascular type, } \\
\text { plasma cell type and mixed type }\end{array}$ \\
Deep, painless, gradually grew tumor & Lobulated, multi-nodular, well defined & $\begin{array}{l}\text { Divided into well-differentiated type, } \\
\text { dedifferentiated type, myxoid type } \\
\text { and pleomorphic type }\end{array}$ \\
Mheochromocytoma & $\begin{array}{l}\text { High blood pressure, headaches, } \\
\text { palpitations, high metabolic state, } \\
\text { high blood sugar, sweating }\end{array}$ & $\begin{array}{l}\text { Roundly, brown-yellow, internal } \\
\text { hemorhage, necrosis or cystic } \\
\text { degeneration }\end{array}$ & $\begin{array}{l}\text { Large irregular polygon cells, cells can } \\
\text { be stained by chromium salts }\end{array}$ \\
& $\begin{array}{l}\text { Different performances because of } \\
\text { different primary tumors, lack of specificity }\end{array}$ & Various & Various \\
\hline
\end{tabular}

\section{Conclusions}

In conclusion, unicentric retroperitoneal $C D$ is a rare disease that is often misdiagnosed due to the nonspecific clinical manifestations. The final diagnosis depends on pathologic examination. Complete surgical resection of the tumor, either laparotomy or laparoscopy, is the best therapeutic alternative for unicentric CD.

\section{Consent}

Written informed consent was obtained from the patient for publication of this case report and any accompanying images. A copy of the written consent is available for review by the Editor-in-Chief of this journal.

\section{Competing interests}

The authors declare that they have no competing interests.

\section{Authors' contributions}

WS acquired data and drafted and revised the manuscript. CSW was the pre- and postoperative treatment team and revised the manuscript. CSL and XJF were responsible for surgical management and revised the manuscript. All authors read and approved the final manuscript.

\section{Acknowledgements}

The authors gratefully acknowledge the assistance of second author (Dr. Shan-wen Chen MD) for his critical review of this manuscript. Furthermore, we are grateful to the members of the Department of Urology for the care of this patient.

\section{Author details}

${ }^{1}$ General Surgery, The fourth affiliated hospital Zhejiang University School of Medicine, Shangcheng Road NO.N1, Yiwu, Zhejiang 322000, China. ${ }^{2}$ Urology Surgery, The first affiliated hospital Zhejiang University School of Medicine, Qingchun Road No. 79, Hangzhou, Zhejiang 310000, China.

Received: 9 October 2015 Accepted: 30 December 2015

Published online: 06 January 2016

\section{References}

1. Castleman B, Iverson L, Menendez VP. Localized mediastinal lymph node hyperplasia resembling thymoma. Cancer. 1956;9:822-30.

2. Keller AR, Hochholzer L, Castleman B. Hyaline-vascular and plasma-cell types of giant lymph node hyperplasia of the mediastinum and other locations. Cancer. 1972;29:670-83.

3. Yildirim $H$, Cihangiroglu M, Ozdemir $H$, Kabaalioglu A, Yekeler $H$, Kalender O. Castleman's disease with isolated extensive cervical involvement. Australas Radiol. 2005;49:132-5.
4. Chronowski GM, Ha CS, Wilder RB, Cabanillas F, Manning J, Cox JD. Treatment of unicentric and multicentric Castleman disease and the role of radiotherapy. Cancer. 2001;92:670-6.

5. Rosai J. Lymph nodes. In: Rosai J, editor. Ackerman's surgical pathology. 9th ed. St Louis: Mosby; 2003. p. 1877-2017.

6. Roshong-Denk SL, Bohman SL, Booth RL. A 53-year-old white man with right-sided supraclavicular lymphadenopathy. Arch Pathol Lab Med. 2005; 129:945-6.

7. Mallik MK, Kapila K, Das DK, Haji BE, Anim JT. Cytomorphology of hyalinevascular Castleman's disease: a diagnostic challenge. Cytopathology. 2007; 18:168-74.

8. Gaba AR, Stein RS, Sweet DL, Variakojis D. Multicentric giant lymph node hyperplasia. Am J Clin Pathol. 1978;69:86-90.

9. Bowne WB, Lewis JJ, Filippa DA, Niesvizky R, Brooks AD, Burt ME, et al. The management of unicentric and multicentric Castleman's disease: a report of 16 cases and a review of the literature. Cancer. 1999;85:706-17.

10. D'Agay MF, Miclea JM, Clauvel JP. Castleman's disease: a well defined histological pattern for a widely divergent clinical spectrum. Nouv Rev $\mathrm{Fr}$ Hematol. 1989;31:145-8.

11. Corcione F, Caiazzo P, Cuccurullo D, Settembre A, Miranda L, Pirozzi F, et al. Laparoscopic treatment of unicentric Castleman's disease with abdominal localization. J Laparoendosc Adv Surg Tech A. 2005;15:400-4.

12. Brusciano L, Rossetti G, Maffettone V, Napolitano V, Izzo D, Pizza F, et al. Laparoscopic treatment of an uncommon abdominal localization of Castleman disease. Surg Laparosc Endosc Percutan Tech. 2005;15:241-3.

Submit your next manuscript to BioMed Central and we will help you at every step:

- We accept pre-submission inquiries

- Our selector tool helps you to find the most relevant journal

- We provide round the clock customer support

- Convenient online submission

- Thorough peer review

- Inclusion in PubMed and all major indexing services

- Maximum visibility for your research

Submit your manuscript at www.biomedcentral.com/submit 